\title{
Regional Innovation: Regional Leadership in Empowering the Aceh Community during the Covid-19 Pandemic
}

\author{
Agatha Debby Reiza Macella \\ Departement of Public Policy, Faculty of Social and Political Sciences, Teuku Umar University \\ (email: agathadebby@utu.ac.id)
}

\begin{abstract}
Leadership is an important factor that we cannot avoid from the success of community empowerment in an area. Apart from the role of regional leadership that supports all innovations and creativity in society. Aceh Province has great potential to develop superior commodities such as coffee, patchouli, rattan, fisheries, potential for natural beauty and culture. The Covid-19 pandemic which infected almost all regions in and had a significant impact on economic conditions both at the central and regional levels, including in the province of Aceh. This research examines the extent of the role of regional leadership in empowering the people of Aceh during the Covid-19 pandemic and seeing what are the factors that affect regional leadership in empowering the community. The research method used is a descriptive qualitative approach and uses library research techniques. The results of his research show that regional leaders play a role as policy makers, coordinate and communicate with various related parties, carry out empowerment, monitor, and evaluate. Factors that influence internally: personal awareness of the duties and responsibilities of leaders, strong commitment, clarity of division of tasks, good communication between actors. External factors: The existence of local potential that should be empowered, the existence of joint commitment from the private sector, village government, universities and the community, the existence of positive support and acceptance and the economic and social conditions at that time.
\end{abstract}

\author{
Keywords: \\ leadership; community empowerment; Aceh
}

\section{Introduction}

Indonesian society is currently entering the global era. We can understand globalization as a process characterized by increasingly diverse mobility on the face of the earth in the form of physical mobility, money, images, goods, and waste, which are now occurring across communities.

The aforementioned developments change the role of the local government which was originally the main development role where the local government is both a regulator and a 
significant development actor. The DPR members decide what can be done and what cannot be done, while the social experts provide intervention models and suggestions on what to prioritize and what not. The role of local government has shifted to become a facilitator where the government has certain limitations in managing the resources, lives and needs of its citizens. Poverty cannot be alleviated only with the social assistance programs provided, but the government needs to do it in other ways, one of which is by empowering the community. It is through community empowerment that the government provides knowledge, training, mentoring, supervision so that the community is able to produce something of added value for them. Not only as additional income, but even a source of their income. In addition, the community also has potential strengths that deserve full appreciation and support by the government, especially local governments. This is because, in essence, local governments better understand geographic and social and cultural conditions and better recognize the potential that exists in the region. Therefore, the role of regional leadership is very important in empowering local communities.

We know that Indonesia is a country that is rich in culture, natural potential, human resources and various other local wisdoms, so it is the government's duty to manage it so that it is able to produce quality products. Where these products are the work of the nation's children which are managed jointly between the community, the government and the private sector through the establishment of small community business units or groups, as an embodiment of community empowerment carried out by the government, the private sector or a collaboration between the two. The collaboration of these three parties should be able to maintain harmony by the government, both at the central and regional levels.

In connection with the foregoing, we need to observe that leadership is an important factor that we cannot avoid from the success of community empowerment in an area. Local leadership is currently an important issue in Indonesia, because many regional leaders realize that the progress and prosperity of a region is due to the commitment of their regional leaders. When regional leaders are loyal and totality in serving and building the community in their area, policies, programs and activities are carried out only to improve the welfare of the community. One of them is by fully supporting community empowerment in the regions, because the role of a very strategic leader is what makes leaders demanded to have good communication competences and be able to channel the needs or desires of the community 
well as well. Apart from the role of regional leadership that fully supports all innovations and creativity of the community, it is the community who in fact is the subject and object of empowerment itself. So, program formulation or community empowerment is actually bottom up.

Aceh Province itself has great potential to develop superior commodities, such as fisheries, coffee, patchouli, rattan, rice, and horticultural commodities, as well as the potential for superior commodities and the tourism sector in September 2018. According to Aceh Province BPS data, the number of poor people in Aceh in September 2018 it reached 15.97 percent. This figure is above the national average of 9.66 percent. This makes Aceh the province with the highest percentage of poor people in Sumatra and ranks 6th in Indonesia after Papua, West Papua, East Nusa Tenggara (NTT), Maluku, and Gorontalo (Serambi Mecca, 2019).

The aforementioned conditions provide dynamics and challenges in managing resources in the regions. As for several regions in Aceh Province that are able to maintain and continue to improve the existence of local products to the public both at national and international levels, such as Banda Aceh City, Kab. Aceh Besar, Aceh Barat District, Aceh Tengah District, Gayo Lues, Aceh Utara. Each region has its own local wisdom, and their respective potentials such as Banda Aceh with aceh bag craft center and Acehnese souvenirs, Aceh Besar with its rattan, North Aceh with its patchouli, Central Aceh and Gayo lues with coffee and natural charm.

Cooperatives, Small and Medium Enterprises, or other home industries as a result of community empowerment in Aceh Province were able to absorb 275 thousand people. However, because currently the whole world is attacked by the Cobid-19 virus which not only attacks humans but also attacks the joints of the country's economy, including Indonesia. In Indonesia alone until October 2020 and attacked 493 cities / districts including Aceh Province. Positive confirmed cases of Covid-19 in Aceh according to data from the Aceh Government Health Service as of October 17, 2020 there were 6,434 cases, where positive cases of Covid-19 attacked evenly in all districts / cities in Aceh with the highest cases in Banda Aceh City with total cases 984 .

The Covid-19 pandemic which has infected almost all regions in Indonesia has certainly had a significant impact on economic conditions both at the central and regional levels, 
including in the province of Aceh. That is why the authors are interested in examining the extent of the role of regional leadership in empowering the people of Aceh during the Covid19 pandemic and seeing what are the factors that influence regional leadership in empowering the community.

Leadership itself is a leader's way or style to influence the behavior of subordinates so that they are willing to work together and work productively to achieve organizational goals (Hasibuan, 2000). The figure of a leader in an organization becomes very strategic, because it is in the position of a leader that this organization can progress or become stagnant and even retreat. The leader becomes someone who is not only inspiring, but he is able to influence his subordinates to do what he wants. So that each of these leaders has their own style, has their own way of advancing the organization.

This is further strengthened by the definition of Soedarmayanti that leadership is an art to influence and take advantage of others by means of obedience, trust, honor in order to achieve the common goal of empowering society (Safitri \& Rahaju, 2015). Howard H. Hyot also stated that leadership is an art to influence human behavior and to guide people (Kartono, 1998). Schein in the leadership module by Asep Suryana (Suryana, 2016) views leadership as the ability to step out of culture, meaning someone who always starts a change process and is more adaptive. The key elements in leadership itself are leaders-followers, people, influence, change and goals to be achieved. Therefore, we can understand that leadership can be widely understood not only as a person's ability, but rather a process in the form of interactions that occur in it. This is in line with Suryana's statement that leadership is in nature abstract, which is produced by humans in the process of their interaction with the environment (Suryana, 2016)

Leadership has several functions such as an instructive function, a consultative function, a participation function, a delegation function, and a control function (Nawawi, 1993), as follows:

a) Instructive function is a direct function and one-way communication means that the leadership gives direction to staff regarding the implementation of decisions.

b) The consultative function is a direct function and two-way communication between the leader and the person they lead, the communication is limited in nature only with certain people who have various information materials they need in making decisions 
c) The participatory function is a direct function, two-way communication and takes the form of implementing the relationship between the leader and staff effectively in accordance with their respective positions and main duties and functions.

d) The function of delegation is the function of giving the authority to make or determine decisions whether with the approval of the leadership or not. Leaders must be willing and able to trust other people, according to their position / position, if they are granted / received the delegation of authority.

e) The control function is a one-way communication that can and can be done through guidance, direction, coordination and supervision.

The five functions above have been implemented in regional leadership in empowering the Acehnese people even during the pandemic period, community empowerment is still carried out by the Aceh government which in this case is carried out by the PMG Office along with the Gampong government and the community by paying attention to the Health protocol when there must be a direct meeting involving some people. Meetings are still being held to collect information and evaluate the course of products from the results of previous community empowerment, and to plan programs and activities for the 2021 fiscal year.

One of the theories of leadership, namely the situational theory initiated by Hersley and Blancard in Hidayat, states that "A person's leadership style is a pattern of behavior shown by that person when influencing other people's activities as perceived by others." This means that the effectiveness of leadership is strongly influenced by ability levels such as maturity and readiness of subordinates to accept or reject leaders. So it can be said that the situational leadership style is a leadership style for guiding, directing, implementing, and also encouraging subordinates to achieve goals and use all existing abilities optimally by combining and adapting to the situation.

The above statement is also supported by Fielder's understanding (Safitri \& Rahaju, 2015) that leadership needs to use a different approach when facing different situations as well for the effectiveness of achieving organizational goals. In addition, according to him, the intelligence of a leader in reading the situation that occurs in his organization is the key to the success of a leadership. The following are the situational factors of the Fielder, namely:

a. Superior relationship with employees 
In this point the emphasis is on the level of trust, respect and also employee disbelief. This relationship is mainly a form of response and a form of participation from followers to their leaders. So that there is a reciprocal relationship between the two. The leader gets input or suggestions from his followers, the followers work and complete the task responsibly according to the rules and direction of the leader and maintain the trust of the leader in him.

b. Task structure

This section emphasizes that tasks are carried out in a structured manner or not. Then there is the provision of clear and firm procedures. In this structure there is clearly an arrangement of assignments, coordination of task implementation, direction or guidance from the leader to his followers which is reflected in the task structure and is contained in a formal written regulation.

c. Position of authority

The position of the leader's authority is based on the formal authority possessed by the leader, meaning that there are applicable rules that regulate the limits of the leader's authority in an organization.

\section{Community Empowerment}

Community empowerment in the RI Minister of Home Affairs Regulation Number 7 of 2007 concerning Community Empowerment Cadres article 8 Paragraph 1 is a strategy used in community development as an effort to realize capability and independence in the life of the community, nation and state. Eko Sutoro also explained that empowerment is a process of developing, independent, self-empowering, strengthening the position of the community at the lower level against the pressing forces in all fields and sectors of life (Sutoro, 2002). The concept of empowerment can also be understood from two perspectives: first, empowerment is interpreted in the context of placing a position as a community.

The position of the community is not an object of beneficiaries that depends on gifts from outside parties such as the government, but in a position as subjects who act independently but remain the responsibility of the state such as providing public services in the fields of health, education, housing, and so on. An independent society as a 
participant means opening up space and capacity to develop creative potential, controlling the environment and its own resources, solving problems independently, and taking part in determining the political process in the realm of the state. The community participates in the development and governance process (Sutoro, 2002).

Empowerment includes not only strengthening individual members of society, but also its institutions. Inculcating modern cultural values, such as hard work, frugality, openness, and responsibility are the main parts of this empowerment effort. community empowerment is closely related to stabilization, culture, and the practice of democracy. Community empowerment can be carried out by many elements: government, universities, non-governmental organizations, the press, political parties, donor agencies, civil society actors, or by local community organizations themselves. The empowerment process can take place more strongly, comprehensively and sustainably if the various elements build partnerships and networks based on the principles of mutual trust and respect (Sutoro, 2002).

Community empowerment can be viewed as an activity to create conditions in which society always has the potential to be developed. Then it is also seen as a step to strengthen the local potential that is owned, and is also seen as an activity to protect the weak from the strong so that the community does not depend on assistance or gifts but they are able to be economically independent. As is the case, according to Wikirannolo and Riant Nugroho in Safitri, who conveyed that empowering the community means enabling and empowering the community (Safitri \& Rahaju, 2015).

Thus the ultimate goal is to make society independent, enable, and build the ability to advance towards a better life in a sustainable manner (Cholisin, 2011). The concrete steps taken in community empowerment begin with the local government starting from the provincial, city / district level, down to the village level, which should provide space for the community to provide their creative and innovative ideas or ideas, then also create a conducive climate or atmosphere. . According to Kartasasmita, real steps in community empowerment are further strengthened by providing various inputs and opening access to various opportunities that will make the community more empowered (Kartasasmita, 1996). 
According to Adhi Iman Sulaiman, a development communication expert and community empowerment, an effective empowerment program is to involve the community from planning, implementation to program evaluation, where community involvement is needed to identify and analyze problems to the potential of the various resources they have (Puspitasari). , 2020). Through this community empowerment, new jobs can be created so as to reduce the number of unemployed. Especially during the Covid-19 pandemic, of course, community empowerment programs are very much needed, so that people can survive with entrepreneurship made through community empowerment programs facilitated by the local government.

\section{Methods}

The method in writing this article is a descriptive qualitative approach and uses the Literature Study Technique to collect factual data and supporting documents in accordance with the research object, such as through books, journals, reports, and other relevant documents. Miles and Hubberman (Reiza Macella, 2020) describe that all the data that has been collected is then processed by adjusting the research questions by reducing data, presenting data and drawing conclusions.

\section{Results and Discussion}

1. The role of regional leadership

Community empowerment is carried out as a form of social development, where the development is no longer only centered on infrastructure development but one that has far-reaching and significant impacts is by building the community through the potential that exists in each region. Now in Indonesia, in line with the implementation of regional autonomy, the Ministry of Rural and Remote Areas and Disadvantaged Areas is also supported by the existence of Permendes No. 17 years old 2019 regarding general guidelines for the development of village community empowerment makes the role of local leadership starting from the governor, mayor / regent, to the village head play an active role in planning strategies, programs to activities then coordinating with related parties such as universities, the private sector and the community, of course, to synergize in succeed in community empowerment. 
This has also been done by the Aceh provincial government which is committed to empowering the community through village empowerment and is managed by the Gampong Community Empowerment Service in all cities and districts in Aceh. This service was formed several years ago to be precise in 2016, based on Aceh Qanun Number 13 of 2016 concerning the Formation and Composition of Aceh Apparatus and PERGUB no 117/2016 concerning the position, organizational structure, duties, functions and work procedures of the Aceh community empowerment service changed to Aceh Community and Gampong Empowerment Service (DPMG).

Through this service, the implementation of community empowerment is controlled and evaluated. The PMG Office together with the Gampong Government work together in implementing community empowerment in the village. In addition, community empowerment in Aceh is included in the Aceh government's flagship program at the seventh point, namely Creative Aceh. This creative Aceh encourages the growth of industries in accordance with the potential of regional resources and protects the products produced through the provision of production centers based on local potential resources and oriented to local markets (Humasaceh.go.id). Activities related to the aceh creative mission and programs, such as the development of natural resource potential through the Application of Innovations. The Gampong Community Empowerment Service has the main task of carrying out government affairs and development in the fields of governance, development and empowerment of mukim and gampong communities.

Based on the foregoing, the commitment of the regional leaders of Aceh province to community empowerment is clearly seen through the vision, mission and superior programs of the Aceh government which are then coordinated by forming a special PMG Office to manage community empowerment, whether related to policy formulation, policy implementation, monitoring, evaluation, implementing administration and coordination between agencies related to the empowerment of the Acehnese people. Coordination has been carried out starting from the Aceh Governor who then coordinates directly with the Aceh PMG Office, the Aceh PMG Office coordinates with the PMG Office at the district and city levels which then coordinates with the gampong government which will be empowered later. 
As with some community empowerment that has been carried out during the pandemic, such as laying hens in Cut Kumbang village, Seunagan district, Kab. Nagan Raya, which has succeeded in developing chicken livestock since 2018 even though during the Covid-19 pandemic. The empowerment of the community in the livestock sector is managed by local BUMG and generates Rp. 1,875,000 per day. Then in the village rambong payong Kab. Bieureun produces teabags from Moringa leaves accompanied and mentored by DPMG Bieureun together with DPMG Aceh (DPMG Aceh, n.d.)

Aceh itself is one of the regions in Indonesia which is rich in natural potentials such as fisheries, coffee, patchouli, rattan and also beautiful natural charm that can be used to empower people through tourism. This natural potential is the superior product from Aceh. As in Aceh Besar, which has superior products such as rattan, these products are made by groups that are members of the home industry and MSMEs. Where the group involved village residents, especially women, as rattan craftsmen. The marketing is not only to Indonesia but abroad such as Malaysia and its surroundings. However, rattan products in Aceh are still unable to compete with rattan products in Java because of the limited ability of craftsmen to use certain machines to support the production process.

In addition, Central Aceh has superior potential in the form of Gayo coffee, its natural and cultural charm which is known to the international community. This is a local potential that can be empowered by the community. Of course, through this a group was born a business group that involved the local community. In addition, there is also tourism potential that can empower the community, such as in the village of Agusen, district. Gayo Lues, formerly known as Ganja Village, was due to changes made by the Balngkejeren sub-district head at that time who made new breakthroughs to improve and empower his village through community empowerment based on tourist villages. The breakthrough has been carried out such as education for the community related to regional potential (HM et al., 2020), providing entrepreneurship training \& English, infrastructure development by inviting USAID Lestari, and cultivating coffee plants. Once again we can see that local leadership plays an important role in empowering the community. When regional leaders commit to community empowerment, creativity and innovation will emerge as contained in programs and activities 
Supporting the above statement that leadership commitment affects the success of regional leadership, of course, cannot be separated from the involvement of other actors as followers as stated in the Situational Theory. Likewise in the implementation of community empowerment involving the PMG Office, Gampong government, nongovernmental organizations, private sector, universities and also the community as in BUMG Rambong Payong Kab. Bieruen who is with DPMG. Then patchouli processing which will later be used as a patchouli tourism village in the village of Rantoe Sabon Aceh Jaya which was initiated by the district government. Aceh Jaya is supported by Bank Indonesia, in collaboration with ARC Unsyiah, and the Makmue Beusare farmer groups who can later empower the village community.

Then, with the bottom-up communication carried out by the leadership during the monitoring and evaluation process, the leadership will know what the shortcomings and desires of the community are regarding the empowerment of the local community. This is being carried out by the Aceh government through the Aceh PMG Office which monitors and evaluates several gampongs in Aceh such as Gampong Kubu, West Aceh which produces water hyacinth handicraft products, in the village of Lubuk Pusaka, Kab. North Aceh, which produces turmeric processed by women, in the village of Term Alue Bie, Kab. Bieureun which produces floating fish feed pellets. In the monitoring and evaluation process, the community and gampong government demonstrated that they were still constrained by inadequate machinery, lack of community skills and the absence of copyright protection so that this needs to be assisted by the local government to overcome these obstacles (DPMG Aceh, 2020). Aceh's regional leadership plays a role in establishing and maintaining communication with various parties involved in community empowerment, especially to the community itself as the subject and object of empowerment.

He results of community empowerment in the form of products can later be assisted by the government to be marketed to the public. In addition, the people who are involved in empowerment can increase their production capacity by joining to become umkm, which will then be given capital assistance by the government. So that it can increase the turnover of product sales and later can increase public opinion so that the level of community welfare also increases and can reduce poverty, especially in the Aceh region. 
One of the innovations made by the Aceh government is by promoting local MSME products and community empowerment through exhibitions or expos which are held annually by the Aceh provincial government and there is also a village innovation week organized by the Aceh PMG service specifically to promote good technology products. use or finished goods as a result of community empowerment. In addition to direct promotion, the government also facilitates the marketing of local Aceh products through e-commerce owned by the Aceh government. So that anyone, anytime, anywhere will be easier to find, find and buy local Aceh products.

2. Factors Affecting Regional Leadership in Empowering Communities

The author examines that in looking at the factors that influence there are two sides, namely internally and externally. Internal factors are factors that come from within, while external factors are factors that come from outside such as organizational conditions, attitudes of subordinates, environmental conditions and so on. Internal factors that influence regional leadership in empowering communities such as:

a. There is personal awareness of the duties and responsibilities of regional leaders in managing regional potential optimally and providing welfare for the people in the area

Of course, with the awareness that as a leader who has been sworn in and given the trust of the community in holding a good position at the provincial, city / district level to the village, this is what makes a person always and will work in totality for the advancement of his area including the people in it.

b. There is a strong commitment to improving the community economy through community empowerment

c. The ability of a person in leadership contains certain elements, namely commitment, which is then actualized responsibly, discipline and other behaviors as part of the organization. A strong commitment in holding firm to a position is a very determining factor in how leadership works. In terms of empowerment in Aceh, as the author has described in number 1, the commitment of Aceh leaders is seen in the Vision and Mission and the Qanun that has been drafted, namely Aceh Qanun Number 13 of 2016 concerning the Formation and Composition of Aceh Apparatus and PERGUB no 117/2016 on position, The organizational structure, 
duties, functions and work procedures of the Aceh community empowerment agency changed to the Aceh Community and Gampong Empowerment Service (DPMG). In addition, the commitment of the PMG Office as the manager of community empowerment is also very important in supporting the success of community empowerment in Aceh.

- There is a division of tasks through a clear assignment structure and rules

Community empowerment in Aceh itself is managed directly by the Gampong Community Empowerment Service as an extension of the governor in implementing community empowerment. In terms of the main function, the PMG Office manages community empowerment, whether related to policy formulation, policy implementation, monitoring, evaluation, administration and coordination between agencies related to the empowerment of the Acehnese people as regulated in PERGUB $117 / 2016$.

- Able to establish communication networks with various parties outside the government

This ability to communicate is also the capital in empowering the community. Because regional leadership will certainly be more optimal by involving various parties such as the private sector through its CSR program which is then supported by its implementation by the Aceh government, universities that carry out community service through $\mathrm{KKN}$ for students and tri dharma colleges carried out by lecturers. Where in its implementation requires cooperation between universities and local government. With good communication, cooperation will also be well established. So that the process of community empowerment is not only a burden borne by the Aceh government, especially considering the Covid-19 Pandemic, of course, on a very limited budget. Therefore, cooperation between the private sector, non-governmental organizations, village government and universities is very supportive of regional leadership in empowering communities, especially in Aceh

Then external factors that affect regional leadership in empowering communities in Aceh such as:

- The existence of local potential that should be empowered by the local community 
The richness of local potential and Aceh's superior commodities such as coffee, rattan, patchouli, high-quality fisheries and also its charming natural charm are the materials or input for the Aceh government to formulate what programs or activities can increase regional income and improve the community's economy and can reducing regional poverty rates through the processing of local potentials and superior commodities in Aceh. Each district / city itself has realized the potential of their respective regions and cultivates this potential by embracing related agencies such as the PMG Service and the UMKM Cooperative Office, the village government, the private sector and the local community as well as coffee commodities that are developed and empowered on the land of Gayo Lues, Aceh. Tengah, then rattan which is the center of products in Aceh Besar and Banda Aceh then Moringa Leaf Tea becomes a product of the district. Bierueun, Turmeric Processing in Kab. North Aceh, water hyacinth crafts in West Aceh, patchouli oil in North Aceh which is the second highest quality in the world, and so on.

- There is a joint commitment from the private sector, village government, universities and the community

This commitment that continues to be built and strengthened is what will later affect the running or success of Aceh government activities or programs carried out at the village level. As with the agusen gampong community empowerment program in Gayo Lues Regency, which jointly empowers the village to become a tourist village. Several universities in Aceh have collaborated with the Aceh Government such as Syiah Kuala University, Malikulsaleh University, Teuku Umar University, and other universities to carry out community service, for example in the form of community empowerment itself. Through the cooperation that exists between these actors, leadership will run optimally so that the goal of implementing community empowerment can achieve optimal results.

- There is positive support and acceptance

This positive support and acceptance is a supporting factor for the success of leadership in the organization. As explained by Philip (Suryana, 2016) that leadership as a process can be grouped into several parts, for example, such as interactions between various actors, both as leaders and as followers, interactions 
are influenced by the situation in which the interactions take place, and group closeness. Leaders cannot actualize their leadership without positive acceptance from their followers. No one follows his orders and the leadership will not work. So it is very important when with a strong leadership spirit, clear task structure, good communication coupled with positive respect from followers, in this case the Aceh PMG Service, District / City Level PMG Service, District / City Government, Gampong Government who participate in carrying out the task. , in essence, their function as public servants includes carrying out community empowerment in order to improve their welfare with full responsibility, discipline in accordance with applicable regulations. That way, Aceh's regional leadership in community empowerment runs well and is integrated with one another.

Apart from government elements, there are also other actors involved in community empowerment in Aceh, namely the private sector with the CSR program in collaboration with the government, universities through student community service activities and community service carried out by lecturers by embracing local regional government. The most important thing here is active community involvement not only as an object but also as the subject of community empowerment. All actors carry out their respective roles, carry out their duties and jobs in community empowerment according to the portions, rules and procedures that have been set by the government.

- Economic and social conditions at that time

The economic condition of both the region and the condition of the community which is considered far from prosperous, where the poverty rate is still high and the unemployment rate is also high, so that regional leaders and their staff formulate a policy that can be implemented in order to improve community welfare, as well as create jobs through community empowerment. Especially with the covid-19 pandemic, the government, through regional leadership, innovates and tries to continue to facilitate the implementation of community empowerment. Given that the impact of Covid-19 is not only on the loss of a person's life but the economy is also stagnating. In addition, the social conditions of the Acehnese people which were affected by the past conflict, followed by the impact of the 2004 tsunami left a special 
grief and affected the social conditions of the Acehnese people, where there are still many of them who do not go to school, are left behind and are isolated so it is necessary to be empowered so that later the community is able to independent to produce a product or service that is very valuable and increase their income as small entrepreneurs. That is why the Aceh local government is working hard by involving various parties to actively participate in empowering the Acehnese community through the flagship program "Aceh Kreatif" which is implemented in all cities / districts in Aceh.

\section{Conclusion}

The Aceh provincial government is committed to empowering the community through gampong empowerment and is managed by the Gampong Community Empowerment Service based on Aceh Qanun No.13 of 2016 concerning the Formation and Composition of Aceh Apparatus and PERGUB no 117/2016 on the position, organizational structure, duties, functions and work procedures of the empowerment agency the Acehnese community has changed to the Aceh Community and Gampong Empowerment Service (DPMG). Community empowerment in Aceh is included in the Aceh government's flagship program, namely Creative Aceh. Activities in it such as developing natural resource potential through the Application of Innovations. The commitment of the regional leaders of Aceh province to community empowerment is clearly seen through the vision, mission and superior programs of the Aceh government which are then coordinated by forming a special PMG Office to manage community empowerment, both related to policy formulation, policy implementation, monitoring, evaluation, administrative implementation and coordination between agencies related to the empowerment of the Acehnese people.

Regional leadership plays an important role in empowering the community. When local leaders are committed to community empowerment, creativity and innovation will emerge in their programs and activities. The success of regional leadership certainly cannot be separated from the involvement of other actors as followers as stated in the Situational Theory. In the implementation of community empowerment that involves the PMG Office, Gampong 
government, non-governmental organizations, the private sector, universities and the community.

The presence of the Aceh regional leadership as a formulator of strategies, plans, and programs as well as Aceh community empowerment activities through the Aceh PMG Service as a regional public organization managing community empowerment in Aceh. Coordinating with the village government, the private sector, universities, NGOs and the community with socialization, FGD, coordination meetings which are held regularly. Regional leadership also carries out activities in cooperation with related actors in proportion to their respective positions and roles. In addition to monitoring in the form of assistance, field visits to evaluation so that later the government in this case will be represented by the Aceh PMG Service to get feedback from the community regarding obstacles during the production of goods or services, their input and hopes which will then be used as references in formulating activity program plans in the next fiscal year.

Aceh's regional leadership plays a role in establishing and maintaining communication with various parties involved in community empowerment, especially to the community itself as the subject and object of empowerment. The results of community empowerment in the form of products can later be assisted by the government to be marketed to the public. Marketing is carried out at the Aceh UMKM exhibition or expo every year, then when the gampong Innovation Week is also held annually by moving locations according to the point of the PMG Office, and is also marketed through online media with e-commerce owned by the Aceh government which is specifically made to promote Aceh local products so that anyone, anywhere can buy and see various kinds of local Aceh products.

Internal factors that influence regional leadership in empowering the community such as personal awareness of the duties and responsibilities of regional leaders in managing regional potential optimally and providing community welfare in the area, a strong commitment to improving the community economy through community empowerment, distribution of tasks through structures clear assignment and rules, Able to establish communication networks with various parties outside the government. External factors that affect regional leadership in empowering communities in Aceh, such as local potential that should be empowered by the local community, positive support and acceptance, economic and social conditions at that time. 
The suggestions that the author gives for the implementation of empowerment of the Acehnese people during the pandemic are as follows:

a) The Aceh Government through the Aceh PMG Service can continue to increase cooperation between universities, BUMN, and private companies that can help finance the implementation of empowerment, and also actively participate in carrying out community empowerment

b) The Aceh government collaborates with the Cooperative and UMKM offices to improve knowledge and business skills for all village communities, including youth groups, mothers, and fathers so that later the results of community empowerment are able to create new entrepreneurs and later open job opportunities

c) Universities and the private sector are always encouraged to do community empowerment to help the government, which is impossible for everything the Aceh government to do. However, it requires the cooperation of various parties.

d) Periodically the City / District Government of Aceh holds FGDs or meetings that invite academics, village community leaders. Private companies, NGOs, successful entrepreneurs in order to get input and even new ideas for future community empowerment planning.

e) Provide education to gampong government and gampong community that community empowerment starts from the village. So that later the community will participate more and feel they have a joint effort in the village in order to empower the community

\section{References}

\section{Book}

Hasibuan, M. S. (2000). Manajemen dasar, pengertian dan Masalah. Bumi Aksara.

Kartasasmita, G. (1996). Pembangunan untuk Rakyat Memadukan Pertumbuhan dan Pemerataan. PT. Pustaka Cidesindo.

Kartono, K. (1998). Pemimpin dan kepemimpinan: apakah pemimpin abnormal itu? Raja Grafindo Persada.

Nawawi, H. (1993). Kepemimpinan Menurut Islam. Gajahmada University Press.

Sutoro, E. (2002). Pemberdayaan Masyarakat Desa. Badan Diklat Provinsi Kaltim.

Journal Articles

HM, S., Nasor, \& Yanti, F. (2020). Upaya Pemerintah Dalam Pemberdayaan Masyarakat Islam 
Berbasis Desa Wisata Guna Meningkatkan Perekonomian Masyarakat Di Desa Agusen Kecamatan Blangkejeren Kabupaten Gayo Lues-Aceh Sukri,1. Ijtimiaiyya: Jurnal Pengembangan Masyarakat Islam, 13(1), 53-74.

Safitri, N. A., \& Rahaju, T. (2015). Kepemimpinan Kepala Desa dalam Memberdayakan Masyarakat Desa Pangkah Kulon Kecamatan Ujungpangkah Kabupaten Gresik. Publika, $3(1), 1-16$.

\section{Journal Artichles with DOI}

Reiza Macella, A. D. (2020). Kinerja Organisasi Publik dalam Mendukung Penyelenggaraan Pelayanan di Kantor Kecamatan Johan Pahlawan. Jurnal Public Policy, 6(1), 51. https://doi.org/10.35308/jpp.v6i1.1672

\section{Website}

DPMG Aceh. (n.d.). BUMG Rambong Payong Produksi Teh Daun Kelor. Retrieved October 18, 2020, from https://dpmg.acehprov.go.id/berita/kategori/bidang-pemg/bumg-rambongpayong-produksi-teh-daun-kelo

DPMG Aceh. (2020). Kepala DPMG Aceh Mengunjungi Pabrik Pelet Pakan Ikan Terapung. https://dpmg.acehprov.go.id/berita/kategori/bidang-pemg/kepala-dpmg-acehmengunjungi-pabrik-pelet-pakan-ikan-terapung

Puspitasari, W. (2020). Akademisi ingatkan pentingnya program pemberdayaan di tengah pandemi. Antarajateng. $\quad$ https://jateng.antaranews.com/berita/320858/akademisi-ingatkanpentingnya-program-pemberdayaan-di-tengah-pandemi

Serambi mekah. (2019). Aceh Genjot Potensi Ekonomi. Serambinews.Com.

\section{Website document}

Cholisin. (2011). PEMBERDAYAAN MASYARAKAT (Disampaikan Pada Gladi Manajemen Pemerintahan Desa Bagi Kepala Bagian/Kepala Urusan Hasil Pengisian Tahun 2011 Di Lingkungan Kabupaten Sleman, 19-20 Desember 2011). 19-20. http://staff.uny.ac.id/sites/default/files/tmp/PEMBERDAYAAN MASYARAKAT.pdf

Hasibuan, M. S. (2000). Kepemimpinan Dan Perilaku Organisasi. Raja Grafindo Persada. Kartasasmita, G. (1996). Pembangunan untuk Rakyat Memadukan Pertumbuhan dan Pemerataan. PT. Pustaka Cidesindo.

Kartono, K. (1998). Pemimpin dan kepemimpinan: apakah pemimpin abnormal itu? Raja Grafindo Persada. 
Nawawi, H. (1993). Kepemimpinan Menurut Islam. Gajahmada University Press.

Puspitasari, W. (2020). Akademisi ingatkan pentingnya program pemberdayaan di tengah pandemi. Antarajateng. https://jateng.antaranews.com/berita/320858/akademisi-ingatkanpentingnya-program-pemberdayaan-di-tengah-pandemi

Reiza Macella, A. D. (2020). Kinerja Organisasi Publik dalam Mendukung Penyelenggaraan Pelayanan di Kantor Kecamatan Johan Pahlawan. Jurnal Public Policy, 6(1), 51. https://doi.org/10.35308/jpp.v6i1.1672

Safitri, N. A., \& Rahaju, T. (2015). Kepemimpinan Kepala Desa dalam Memberdayakan Masyarakat Desa Pangkah Kulon Kecamatan Ujungpangkah Kabupaten Gresik. Publika, 3(1), 1-16.

serambi mekah. (2019). Aceh Genjot Potensi Ekonomi. Serambinews.Com.

Suryana, A. (2016). Konsep Dasar Kepemimpinan. Universitas Terbuka.

https://www.pustaka.ut.ac.id/lib/mpdr5301-kepemimpinan-dan-manajemenpendidikan-dasar/

Sutoro, E. (2002). Pemberdayaan Masyarakat Desa. Badan Diklat Provinsi Kaltim. 